\title{
Publisher Correction: Pre-symptomatic Caspase-1 inhibitor delays cognitive decline in a mouse model of Alzheimer disease and aging
}

\author{
Joseph Flores (D), Anastasia Noël(D), Bénédicte Foveau, Olivier Beauchet \& Andréa C. LeBlanc (iD
}

Correction to: Nature Communications https:/doi.org/10.1038/s41467-020-18405-9, published online 11 September 2020.

The original version of this Article contained an error in Fig. 5j, in which the $y$ axis of the graphs on the top part of the panel was

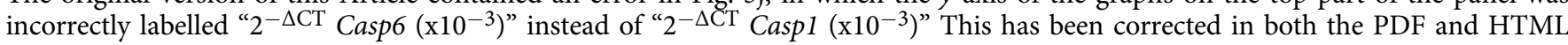
versions of the Article.

Published online: 09 April 2021

\begin{abstract}
(c) Open Access This article is licensed under a Creative Commons Attribution 4.0 International License, which permits use, sharing, adaptation, distribution and reproduction in any medium or format, as long as you give appropriate credit to the original author(s) and the source, provide a link to the Creative Commons license, and indicate if changes were made. The images or other third party material in this article are included in the article's Creative Commons license, unless indicated otherwise in a credit line to the material. If material is not included in the article's Creative Commons license and your intended use is not permitted by statutory regulation or exceeds the permitted use, you will need to obtain permission directly from the copyright holder. To view a copy of this license, visit http://creativecommons.org/licenses/by/4.0/.
\end{abstract}

(C) The Author(s) 2021 